\title{
DERMATOPHYTOSIS CAUSED BY Trichophyton raubitschekii. REPORT OF THE FIRST CASE IN SÃO PAULO, BRAZIL
}

\footnotetext{
Carlos da Silva LACAZ(1), Clarisse ZAITZ(2), Ligia Rangel B. RUIZ(2), Valéria Maria de SOUZA(2), Ana Regina Alencar SANTOS(2), Laura Hitomi MURAMATU(2),
} Natalina Takahashi de MELO(1), Elisabeth Maria HEINS-VACCARI(1), Giovana Leticia HERNÁNDEZ-ARRIAGADA(1) \& Roseli Santos de FREITAS-LEITE(1)

\section{SUMMARY}

The authors report the first case of dermatophytosis caused by Trichophyton raubitschekii in a patient from the State of São Paulo with Tinea corporis lesions localized on the buttocks. Culture on Sabouraud-agar with cycloheximide permitted the isolation and identification of the fungus, and the diagnosis was confirmed by Dr. Lynne Sigler, University of Alberta, Canada. Systemic treatment with fluconazole, $150 \mathrm{mg}$ /week for 4 weeks, in combination with topical treatment with isoconazole initially yielded favorable results, with recurrence of the lesions after the medication was discontinued. This is the fifth case of this dermatophytosis published in the Brazilian medical literature.

KEYWORDS: Trichophyton raubistschekii; Dermatophytosis; Tinea corporis

\section{INTRODUCTION}

In 1981, KANE et al. ${ }^{3}$ reported a new species of Trichophyton isolated from epidermal scales of the skin of a patient from Toronto (Canada), which they called Trichophyton raubitschekii. This was a urease-positive dermatophyte similar to Trichophyton rubrum.

About 41 strains of this dermatophyte were then studied and compared to 10 strains of T. rubrum and T. mentagrophytes.

According to KANE et al. $(1981)^{3}$, this is an anthropophilic fungus predominantly distributed in southeast and southwest Asia and in northeast India. In Brazil, CAIUBY et al. (1996) ${ }^{1}$, in Rio de Janeiro, identified 4 strains of this fungus isolated from Tinea corporis lesions.

The characteristics of this dermatophyte are as follows: colonies of moderately slow growth, elevated and reaching 25 to $30 \mathrm{~mm}$ after 14 days at $25^{\circ} \mathrm{C}$ in Mycosel agar. The colony surface is blood red or reddish brown, radially sulcated or granular and flat, covered with fine brown aerial mycelium. Some cultures may be red-purple in color and smooth, resembling $T$. violaceum. The reverse may present yellowish bands in young cultures. Macroconidia and microconidia are abundant in primary isolations, and may decrease in subcultures. The macroconidia are cylindrical or cigar-shaped, measuring 46-51 $\mu \mathrm{m}$ in length by 4.8-6.3 $\mu \mathrm{m}$ in width. The microconidia are subspherical to spherical, piriform or club-shaped, measuring 4.8-6.4 x 3.2-4.8 $\mu \mathrm{m}$

Dilated rounded cells can be produced in submersed filaments or occasionally by the disaggregation of macroconidia into 1 to 3 cell

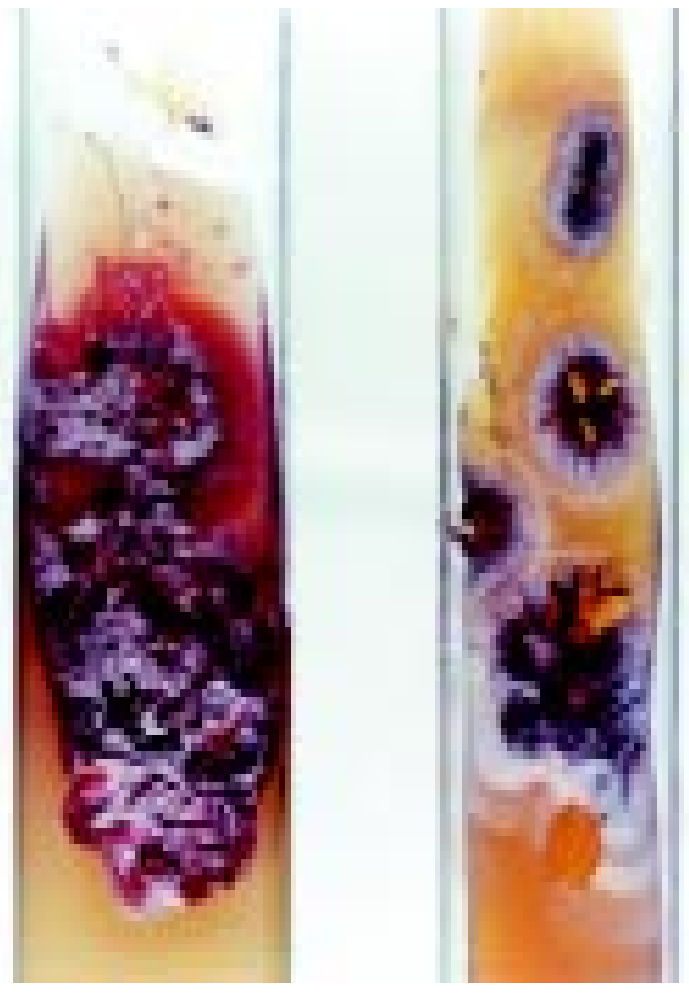

Fig. 1 - Trichophyton raubitschekii. Colonies on potato-agar and Sabouraud-agar with cycloheximide after 20 days at room temperature.

(1) Laboratório de Micologia Médica, Instituto de Medicina Tropical de São Paulo and LIM/53 do Hospital da Clínicas da Faculdade de Medicina da Universidade de São Paulo. (2) Clínica Dermatológica, Faculdade de Ciências Médicas, Santa Casa de Misericórdia de São Paulo - Setor de Dermatologia Infecciosa e Tropical.

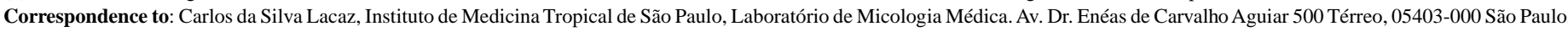
SP, Brasil. Phone: 5511 30667443; FAX 5511 8523622; E-mail: valacaz@usp.br 
LACAZ, C. da S.; ZAITZ, C.; RUIZ, L.R.B.; SOUZA, V.M. de; SANTOS, A.R.A.; MURAMATU, L.H.; MELO, N.T. de; HEINS-VACCARI, E.M.; HERNÁNDEZ-ARRIAGADA, G.L. \& FREITAS-LEITE, R.S. de - Dermatophytosis caused by Trichophyton raubitschekii. Report of the first case in São Paulo, Brazil. Rev. Inst. Med. trop. S. Paulo, 41 (5): 313-317, 1999.
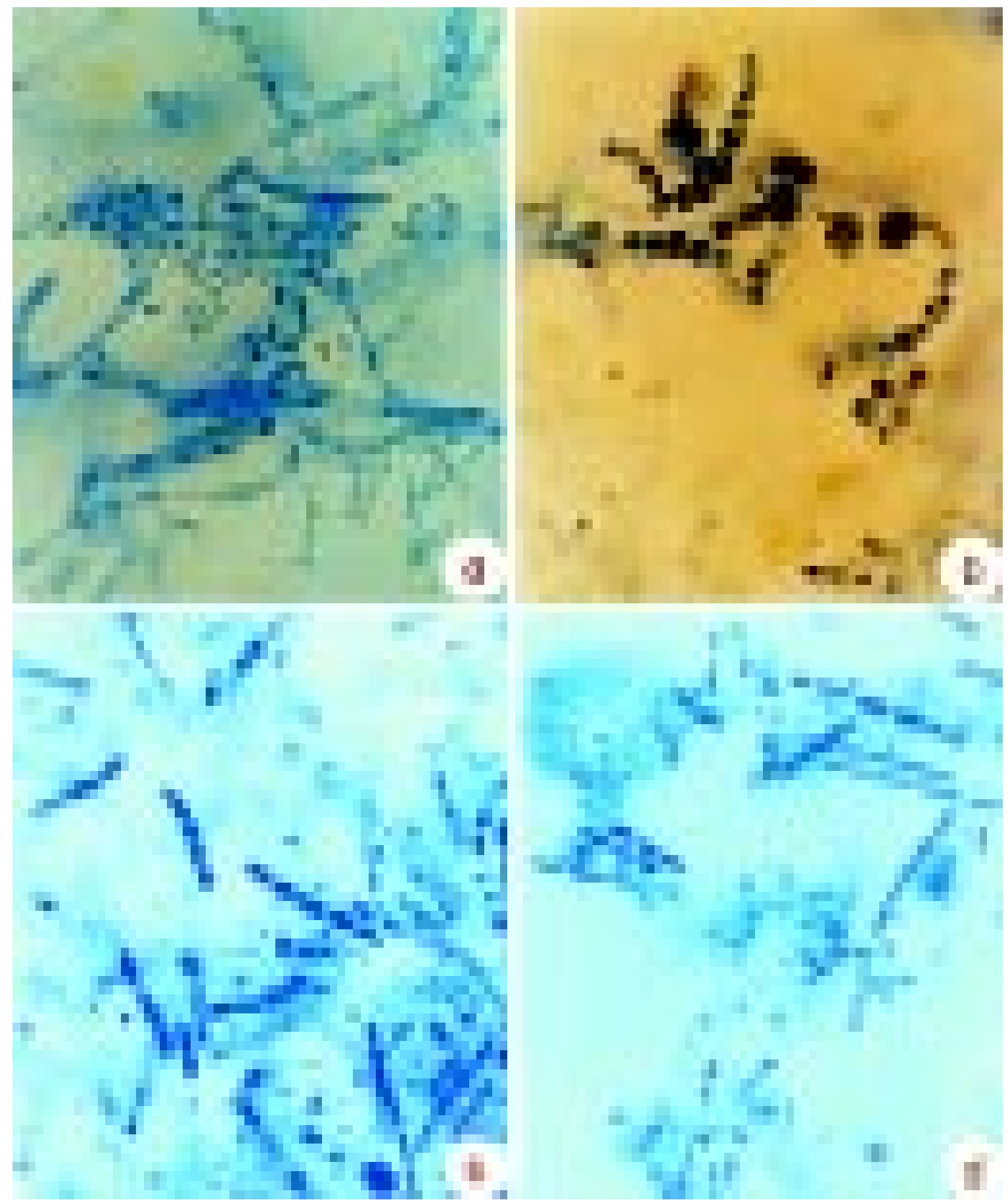

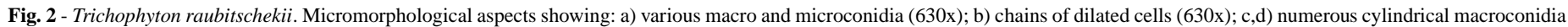
of varying sizes and microconidia (630 and 400x). 
LACAZ, C. da S.; ZAITZ, C.; RUIZ, L.R.B.; SOUZA, V.M. de; SANTOS, A.R.A.; MURAMATU, L.H.; MELO, N.T. de; HEINS-VACCARI, E.M.; HERNÁNDEZ-ARRIAGADA, G.L. \& FREITAS-LEITE, R.S. de - Dermatophytosis caused by Trichophyton raubitschekii. Report of the first case in São Paulo, Brazil. Rev. Inst. Med. trop. S. Paulo, 41 (5): 313-317, 1999.

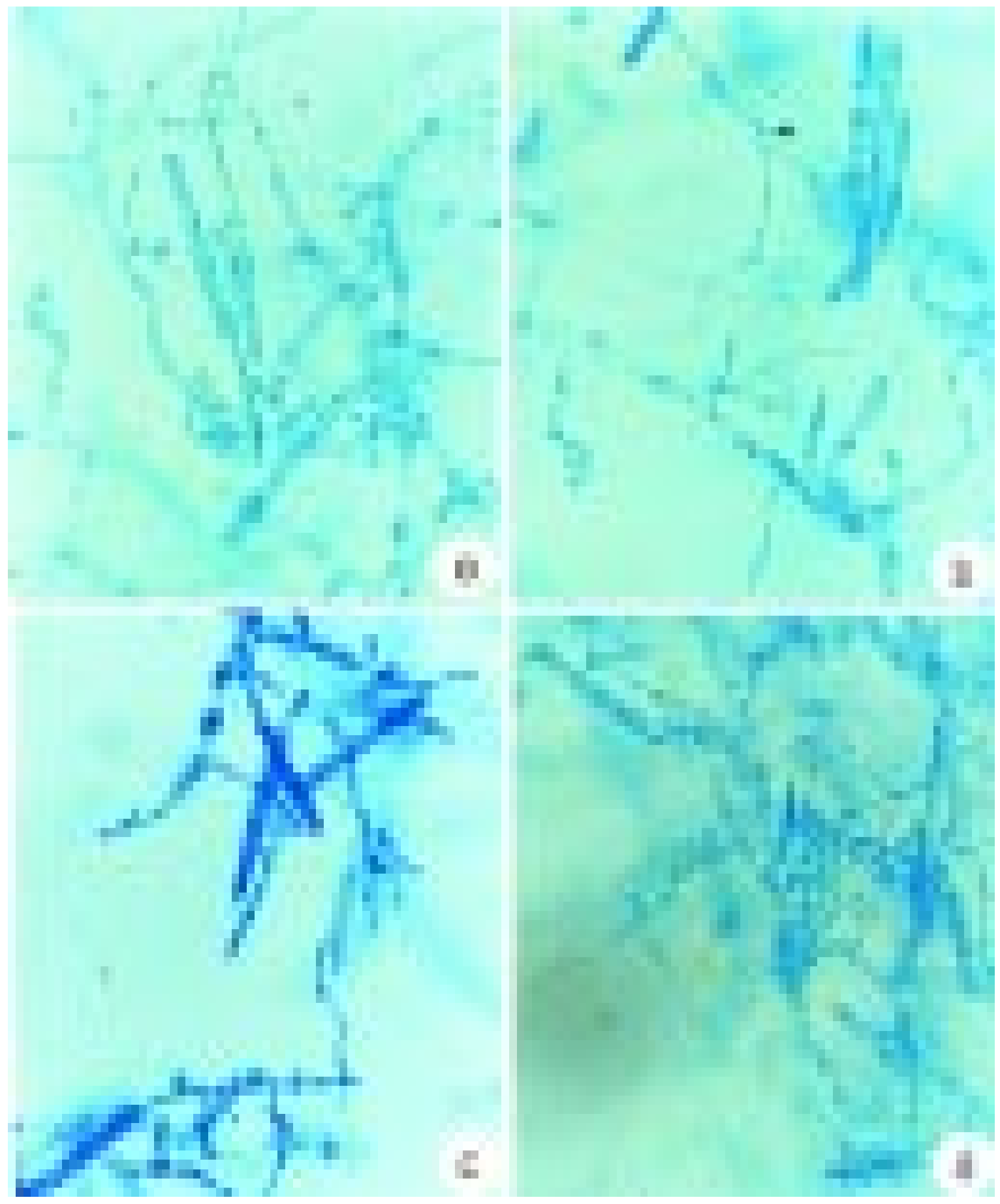

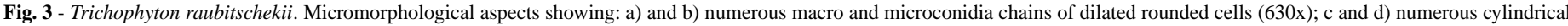
macroconidia of varying sizes and microconidia (630x and 400x, respectively). 


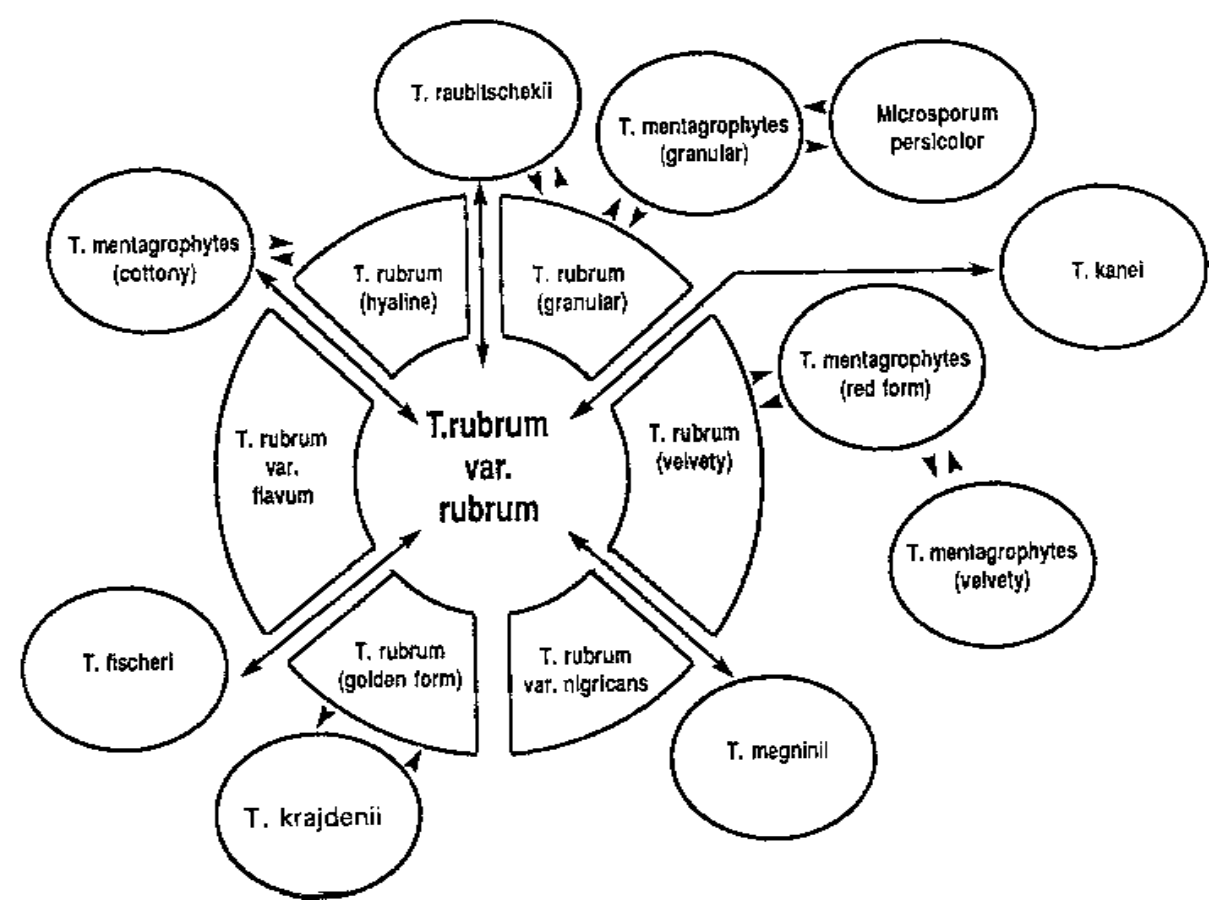

Fig. 4 - Species of the Trichophyton rubrum complex, their variants and morphologically similar species (according to KANE, 1997).

fragments. The fungus grows at $37^{\circ} \mathrm{C}$ and is urease-positive. It does not perforate hair.

The species under study has been named after Prof. F. Raubitscheck, an American dermatologist and mycologist.

The present paper reports the first case of dermatophytosis caused by Trichophyton raubitschekii in a patient with Tinea corporis from the State of São Paulo.

\section{CASE REPORT}

Patient T.A.A., registration number 599 at the Dermatology Clinic of Santa Casa (SP), a white female working as a fruit and vegetable seller, born and living in São Paulo, presented with Tinea corporis lesions localized on the buttocks. Mycologic examination was positive for dermatophyte arthroconidia. Culture on Sabouraud-agar with cycloheximide permitted the isolation of a fungus first identified as Trichophyton rubrum and then finally identified as Trichophyton raubitschekii Kane, Salkin, Weitzman et Smitka, $1981^{3}$ (Fig.1). It is a urease-positive dermatophyte that does not perforate hair in vitro; its macroconidia are cylindrical or cigar-shaped and the microconidia are subspherical, piriform or club-shaped (Figs. 2 and 3).

The patient was treated systemically with fluconazole, $150 \mathrm{mg} /$ week for 4 weeks, in combination with topical treatment with isoconazole. Favorable results were first obtained, followed by recurrence of lesions after the medication was discontinued.

\section{DISCUSSION}

According to KANE et al. $(1997)^{4}$, Trichophyton raubitschekii colonies may be confused with $T$. violaceum or T. rubrum because of the pigment they produce. The lesions they provoke are similar to those of Tinea corporis. Trichophyton raubitschekii has been considered by many mycologists to be a variant of T. rubrum, as is also the case for T. kanei and $T$. fischeri.

T. raubitschekii is quite similar to the velvety form of T. rubrum and is distinguished from the latter by being urease-positive, also producing abundant macroconidia and microconidia in primary isolations. Some macroconidia are rounded, a characteristic rarely observed in T. rubrum. The teleomorph form of $T$. raubitschekii has not been described . KANE et al. $(1997)^{4}$, in a chapter on the "Biological aspects in the identification of dermatophytes" elaborated a figure (Fig. 4) in which the species of the "T. rubrum complex" are presented. T. rubrum var. rubrum, T. rubrum (hyaline variant), T. rubrum (granular variant), T. rubrum (velvety), $T$. rubrum var. nigricans and T. rubrum (golden form) were first considered. In turn, $T$. rubrum is related to $T$. raubitschekii, $T$. mentagrophytes (granular), M. persicolor, T. kanei. T. mentagrophytes (reddish), T. mentagrophytes (velvety), T. megnini, T. krajdenii, T. fischeri, and T. mentagrophytes (cotton-like).

SUMMERBELL \& KANE $(1997)^{5}$, when describing T. raubitschekii reported that in certain variants the colonies produce a red-purple pigment similar to $T$. violaceum. They also pointed out that $T$. raubitschekii is closely similar to the velvety variety of $T$. rubrum, being differentiated 


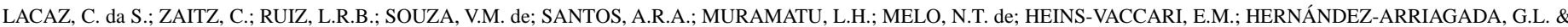
FREITAS-LEITE, R.S. de - Dermatophytosis caused by Trichophyton raubitschekii. Report of the first case in São Paulo, Brazil. Rev. Inst. Med. trop. S. Paulo, 41 (5): 313-317, 1999.

from the latter by being urease-positive. Some microconidia are rounded, a fact that is not common in T. rubrum varieties.

\section{RESUMO}

\section{Dermatofitose por Trichophyton raubitschekii. Registro do primeiro caso em São Paulo, Brasil}

Os Autores registram o primeiro caso de dermatofitose por Trichophyton raubitschekii em paciente do Estado de São Paulo, com lesões de Tinea corporis localizada nas nádegas. O cultivo em ágarSabouraud com cicloheximida permitiu o isolamento e identificação do fungo, cujo diagnóstico foi confirmado pela $\operatorname{Dr}^{\mathrm{a}}$ Lynne Sigler, da Universidade de Alberta, Canadá. O tratamento sistêmico com fluconazol, $150 \mathrm{mg} / \mathrm{semana}$ por 4 semanas, associado ao tratamento tópico com isoconazol ofereceu inicialmente resultados favoráveis, com recidiva das lesões, após suspensão do medicamento. Trata-se do quinto caso publicado na literatura médica nacional.

\section{ACKNOWLEDGEMENT}

We are grateful to Dr. Lynne Sigler, University of Alberta, Canada, for confirming the diagnosis and Creusa Paes Siqueira for typing the manuscript.

\section{REFERENCES}

1. CAIUBY, M.J.; MONTEIRO, P.C.F. \& NISHIKAWA, M.M. - Isolation of Trichophyton raubitschekii in Rio de Janeiro (Brazil). J. med. vet. Mycol., 34: 361-363, 1996.

2. KANE, J. - The biological aspects of the Kane/Fischer system for identification of dermatophytes. In: KANE, J.; SUMMERBELL, R.; KRAJDEN, S.; SIGLER, L. \& LAND, G. Laboratory handbook of dermatophytes. A clinical guide and laboratory handbook of dermatophytes and other filamentous fungi from skin, hair and nails. Belmont, Star Publishing Company, 1997. p. 81-129.

3. KANE, J.; SALKIN, I.F.; WEITZMAN, I. \& SMITKA, C.M. - Trichophyton raubitschekii sp. nov. Mycotaxon, 13: 259-266, 1981.

4. KANE, J.; SUMMERBELL, R.; KRAJDEN, S.; SIGLER, L. \& LAND, G. - Laboratory handbook of dermatophytes. A clinical guide and laboratory handbook of dermatophytes and other filamentous fungi from skin, hair and nails. Belmont, Star Publishing Company, 1997.

5. SUMMERBELL, R.C. \& KANE, J. - The genera Trichophyton and Epidermophyton. In: KANE, J.; SUMMERBELL, R.; KRAJDEN, S.; SIGLER, L. \& LAND, G Laboratory handbook of dermatophytes. A clinical guide and laboratory handbook of dermatophytes and other filamentous fungi from skin, hair and nails. Belmont, Star Publishing Company, 1997. p. 131-191.

Received: 18 June 1999

Accepted: 19 August 1999 